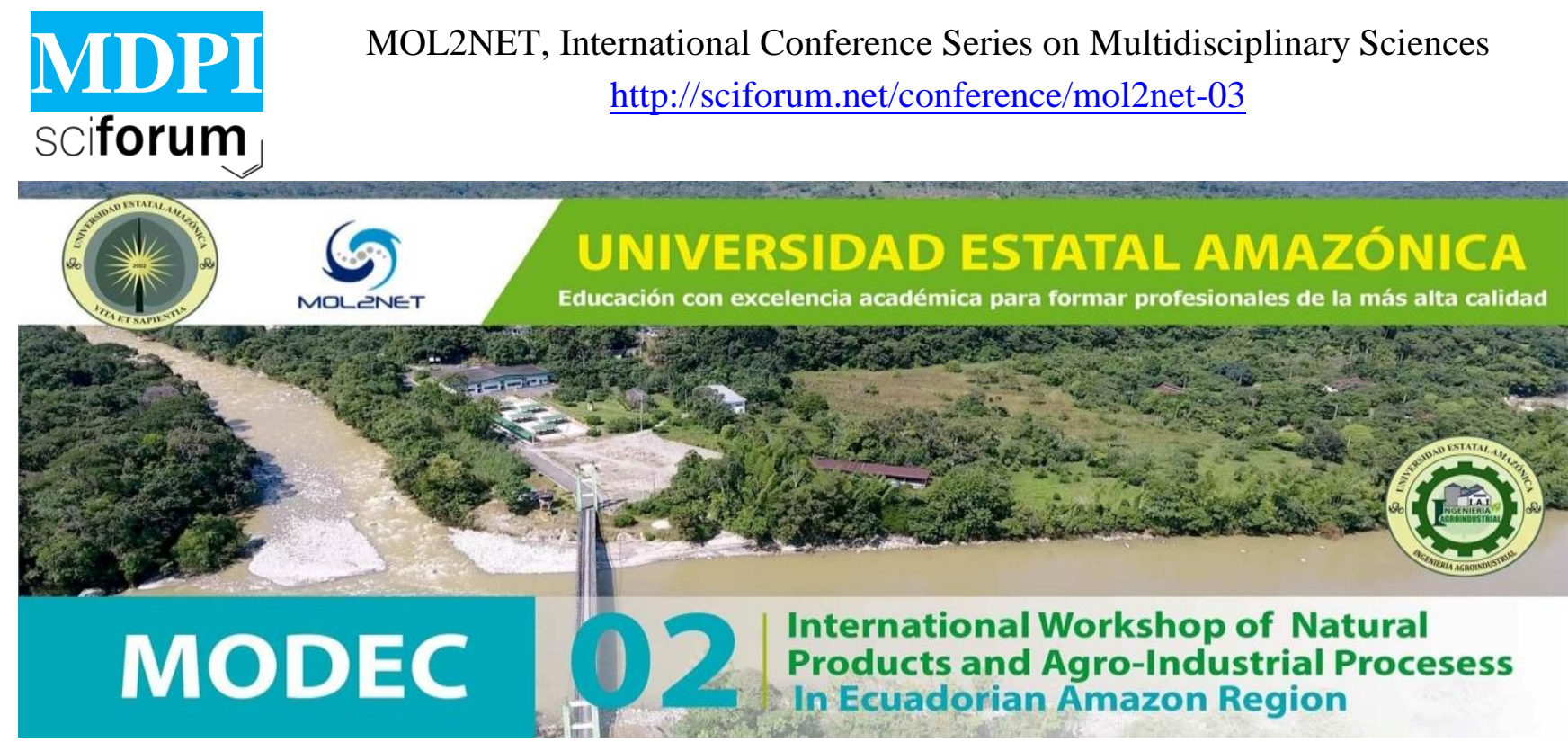

\title{
DESIGN OF INNOVATIVE PRODUCTS FROM ELEMENTS OF THE ECUADORIAN AMAZON
}

Authors: Karla Liliana Salagata Tirado1, Leidy Paola Pico Poma1, Lessly Estefania Ramírez Herrera1, Johnny Osvaldo Guevara Ocampo1, Anthony Ordoñez Barros1, David Sancho Aguilera (e-mail: dsancho@uea.edu.ec) ${ }^{\mathrm{a}}$ y Neyfe Sablón Cossío (e-mail: nsablon@utn.edu.ec) ${ }^{\mathrm{b}}$

aProfessors-Researchers. Amazon State University, Km. 2 1/2, vía Puyo a Tena (Paso Lateral). Tel. 032-888-118 / 032-889-118. Postal Code: 160150. Puyo, Ecuador.

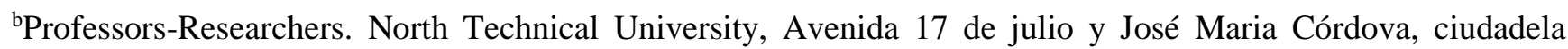
Universitaria Bario el Olivo. Tel. (06) 2997800 Casilla 199. Postal Code: 100150, Ibarra. Ecuador. e-mail corresponding author: nsablon@utn.edu.ec

Abstract.
In the times of the fourth Industrial Revolution, product design reaches a new look. The objective of
this work is to develop a methodology for the design of innovative products based on Amazonian
elements, and the application of this in two practical case studies. Design methodologies were
analyzed, common points were identified between them, a content matrix was constructed for the
definition of design elements. The Amazonian raw material used is chontacuro (larvae of R.
palmarum), a product rich in antioxidants and monounsaturated fatty acids (oleic), and two products
are produced and result in: pâte and sausage with added value for human health. These products
analyze the market, use the benchmarking technique, the form of industrial processing (formulations
and processes) and define improvement actions. This work has a social value, because the larvae of
this insect are part of the basic diet of the communities of the Ecuadorian Amazon.
Keywords: Food, amazon, Ecuador.

\section{Introduction}

The characteristics of the fatty extract of Rhynchosphorus palmarum (chontacuro) make it possible to raise potential use in the food industry; which contributes positively to the food sovereignty of the indigenous peoples of the Ecuadorian Amazon where the larvae are grown and traded (Sancho 2015). 
The high prices and high demand of $\mathrm{R}$ palmarum ensure that productions are easily tradable and profitable; the knowledge on the use of this resource of the forest allows new productive activities, that tributar to the local development of the province of Pastaza of Ecuador (Sancho 2015).

The larvae are considered as a source of protein, fats, vitamins and minerals. Its fat content is abundant and consists mainly of polyunsaturated fatty acids (1.5\%), saturated (36.8\%), monounsaturated $(60.4 \%)$ and unidentified fatty acids $(1.3 \%)$. In addition to being a source of food, its sale has become an economic means for the Amazonian Indians who cultivate and sell the larva, its value varies between 30 and 50 cents on the local markets. There are people who sell them in bulk sporadically, their price then depends on the business between the buyer and seller. In typical Amazonian food establishments, the larvae are sold in different dishes: roasted has the value of $\$ 1$ dollar per unit; in a maize dish consisting of larvae (4 to 5), tender palm stems wrapped in leaves of bijao and cooked to the embers, varies between $\$ 5$ and $\$ 6$ dollars; in other cases they are found to the plate served with green banana and yuccas boiled at prices similar to the maitos.

Its sale in the markets of the canton Pastaza has been frequent for approximately 15 years, being in the beginning marketed to a value close to $10 \mathrm{ctvs}$ dollar. As it was something new and unknown for some people larva sales were directed towards the indigenous and mestizo settlers of the area, knowledgeable of its use as food and ancestral medicine. In the market there are 10 fixed places where you can always find larvae, weekly each of them have between 100-200 units of larvae and sell them without any problems at a cost of 50 cts., In the low sales weeks usually sell 3 units for 1 dollar (this case is not frequent).

The merchants of this animal are indigenous of the Amazon, they comment that can obtain 60 larvae of the palm of chonta, 100-150 of the palm of ungurahua and 100-200 or more in the palm of morete. However, the harvest of the larvae is at different times and in order to reach the maximum yield of each palm they must pass 3-4 weeks approximately.

The main limitation of this food is its easy decomposition when cooking because of the characteristics mentioned, so it becomes a challenge to obtain a product derived from this raw material, the objective of this work.

\section{Materials and methods}

The literature studied is analyzed, (Acuña, 2009; Allende, 2011; Ariza, 2009; Calomarde, 2000; Casp, 2012; Cortés, 2014 ; Cortez, 2000; Chauvin, 2014; Departamento de Organización de Empresas, 2007; Gaither, 2000 ; Jordi, 1989; Lockyer, /s.a/; Machado, 2007; Miranda, 2000; Ramirez, 2009; M. Salvador, 2004; V. Salvador, 2014; Sanchez, 2016; Suh, 1990; Turmero, /s.a/; Wodehouse, 2010), are defined as steps for product design, Figure 1:

$\square$ Idea generation

Product selection

$\square$ Preliminary product design

Construction of the prototype

Testing and evaluation

$\square$ Definitive design of the product 


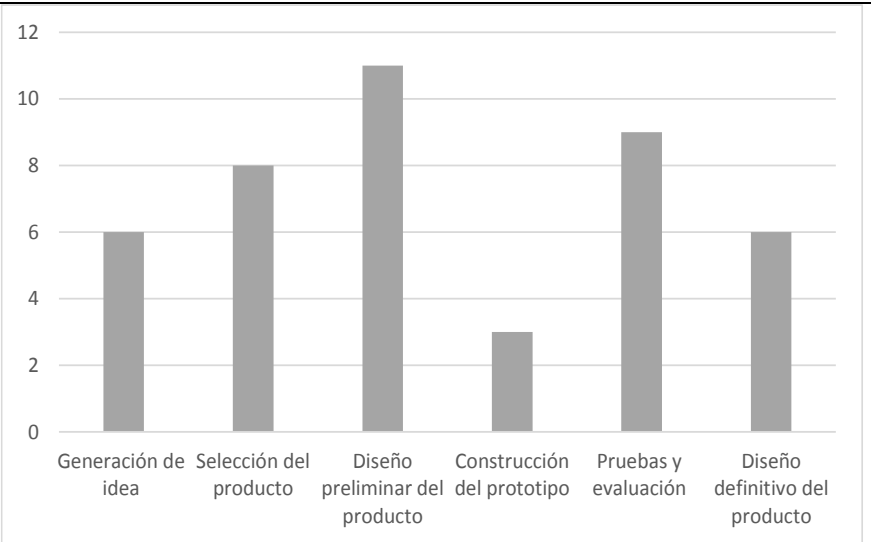

Figura 1: Product Design Steps.

\section{Results and discussion}

In this research larva oil is used as an enriching omega for the production of sausages. Rhynchophorus palmarum is the scientific name of the innovative ingredient of sausage, this larva contains unsaturated fats that are excellent for the body, more protein, which provides a unique added value that differentiate it from other brands. The Palmarun mark is designed as Figure 2. As the name that will represent the product is understood to come from a palm, for the same reason the image that was used is a palm abstraction in general and not specific, Figure 3. The sologan of the brand is EXÓTICAMENTE AMAZÓNICO.

Figure1: Mark the Palmarun

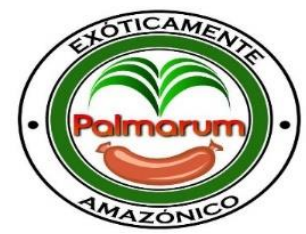

Figure 2: Label

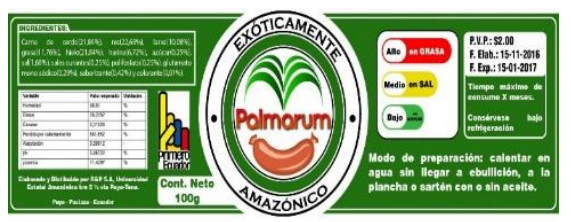

In order to study the market acceptance of the product, the demographic segmentation of the population according to different variables is analyzed, Table 1.

Table 1: Variables of the market segment.

\begin{tabular}{cc}
\hline Targeting Base & Categories \\
\hline Type of & Urban and rural \\
population & $5-54$ years \\
Age & Female and male \\
Sex & Heterosexual, homosexual, bisexual \\
Sexual & High Medium \\
Orientation & and High \\
Social class & Married, single, free marriage, widower, divorced, separated. \\
Civil status & Indigenous, white-European, Asian, black. \\
Race & All \\
Nacionality &
\end{tabular}

In the study of the demand is used the survey and interview to the traders and consumers, with focus to the larva Rhynchophorus palmarum or chontacuro, to know the possible acceptance of consumption of the same, in the province of Pastaza to undertake the possible industrialization of the Figure 2. 
Figure 2: Survey to know the existing demand for a new Amazonian product.

Good afternoon, this is a survey conducted students of seventh Agroindustries. The information you provide us will be used to know the degree of market acceptance of a new Amazon product. The survey will not take more than 5 minutes. Thank you very much for your help.

Age: Year: Sex: F__ M_

1. Know the larva Rhynchophorus palmarum L. commonly called chontacuro or mallón? IF NOT

If yes, continue with the survey.

2. A consumed larva Rhynchophorus palmarum L. commonly called chontacuro or mallón? IF__ NOT

3. What price has paid for the larva Rhynchophorus palmarum L. commonly called chontacuro or mallón?

a) 0.50 cts. b) $\$ 1.00$ c) $\$ 1.50$ d) $\$ 2.00$

4. How the larva Rhynchophorus palmarum L. has been consumed, commonly called chontacuro or mallón: Crude __ b) Roasted __ c) Maito _ d) Grilled ___ e) Other

5. Know the nutritional value of the larva Rhynchophorus palmarum L. commonly called chontacuro or mallón: YES __ NO

6. Consume the larva Rhynchophorus palmarum L. commonly called chontacuro or mallón by its:

a) Taste b) Color c) Odor d) Nutritional value e) Medicinal use f) Other _ which

7. Which of these processed products would you like to consume the larva Rhynchophorus palmarum L. commonly called chontacuro or mallón?
a) Sausage
b) Conserva
c) Oil
d) Pate
e) Others

\section{Results of the test}

Of the 307 gender-related surveys $60 \%$ of 183 people are women and $40 \%$ are men. Of the 307 surveys concerning the city of origin, we conclude that the majority of respondents are from the Ecuadorian Amazon with 85\%, Graph 1.

Of the 307 surveys concerning Rhynchophorus palmarum L., we concluded that approximately $99 \%$ of the people surveyed know the larva and only $1 \%$ do not. Of the 307 surveys concerning the form of consumption of the larva Rhynchophorus palmarum L. we conclude that; $36 \%$ consume it raw, $32 \%$ roast, $20 \%$ in maito and in lower percentages $10 \%$ fried, $2 \%$ has not consumed and with a person who has consumed the griddle.

Of the 307 surveys concerning which of these processed products would like to consume the larva Rhynchophorus palmarum L. we conclude that; $40 \%$ want to consume it in sausage, $31 \%$ in oil, $25 \%$ canned and in lower percentages of 1 and $2 \%$ pâté, oil and none. Graph 3.

Of the 307 surveys on whether he knows the nutritional value of the larva Rhynchophorus palmarum L. we conclude that; $90 \%$ of people surveyed if they knew it while $8 \%$ did not and $2 \%$ did not answer the question.

Of the 307 surveys concerning what he likes about the larva Rhynchophorus palmarum L. we conclude that; $41 \%$ of the respondents liked the larva because of its flavor, $30 \%$ because of its nutritional value, $27 \%$ because of its medicinal use and in a lower percentage of $1 \%$ the color and did not respond, whereas with a non-response showing another and olor. 
Graph 1: Source of respondents .

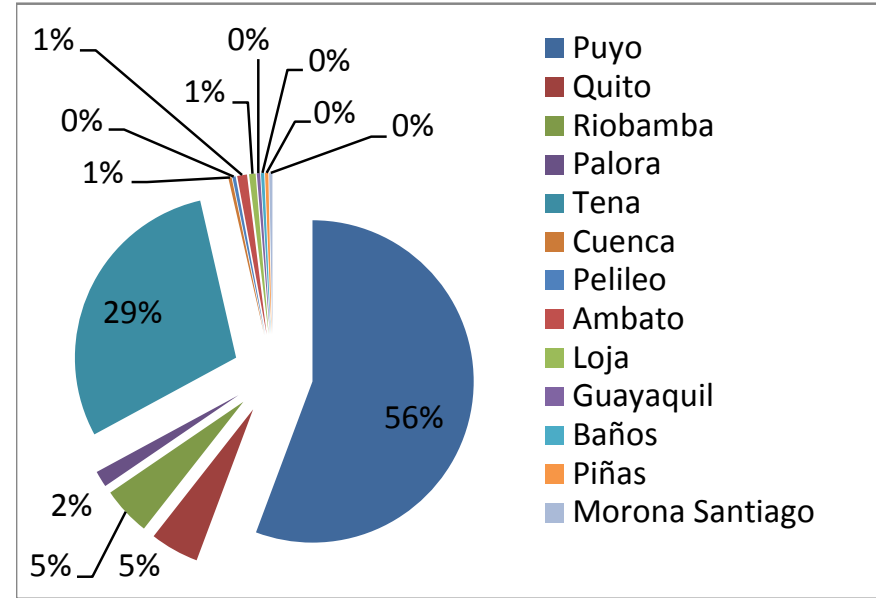

Graph 3: Likes of possible processed products.

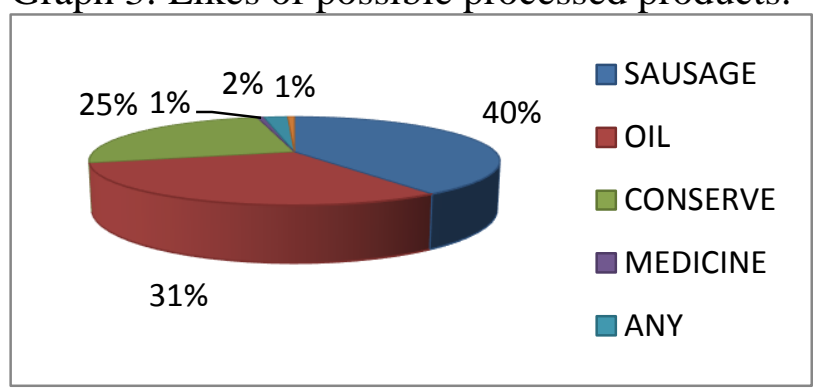

Graph 2: Forms of chontacuro consumption.

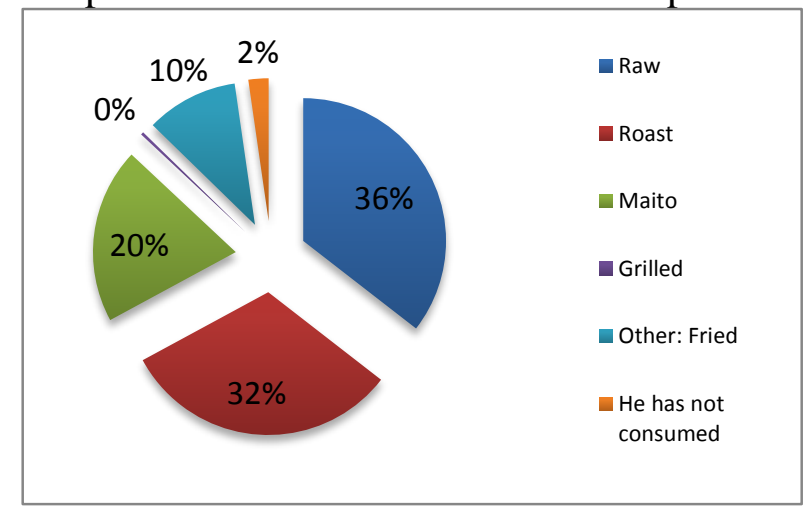

Graph 4: Taste for the larva.

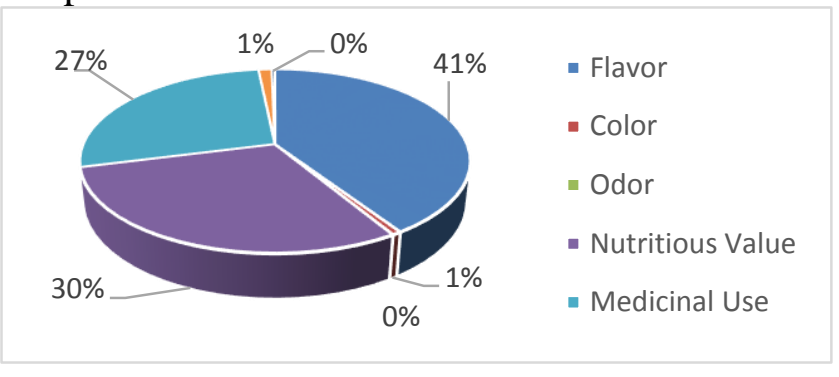

\section{Testing and evaluation}

The competition is analyzed the competition of the products in the market, to determine the characteristics that must be improved in each one of them. The benchmarking technique is used for this analysis. In which parameters such as brand, properties, composition, price, packaging, quantity, quality, packaging, the place where it is manufactured and the place of sale are studied.

Final Product Design

Formulation of the product

The ingredients of the sausage product, Table 2:

\section{Table 2: formulation sausage PALMARUM}

\begin{tabular}{cc}
\hline Ingredients & $\%$ \\
\hline Pork Meat & 24,00 \\
Beef & 30,00 \\
Larvae of R. palmarum & 16,00 \\
Flour & 22,78 \\
Sugar & 3,00 \\
Salt & 1,00 \\
Curing salts & 2,00 \\
Polyphosphate & 0,25 \\
Monosodium glutamate & 0,25 \\
Flavorful & 0,29 \\
Colorant & 0,49 \\
Pork Meat & 0,01 \\
TOTAL & 100 \\
\hline
\end{tabular}

(Sarabia, 2012).

Obtaining Palmarum sausages consists of several operations:

$\checkmark$ Reception: the raw material was selected cleaned and weighed

$\checkmark$ Chopped: in the chopped, the pork and beef is cut into cubes of approximately $4 \mathrm{~cm}$.

$\checkmark$ Frozen: meat cubes as well as fresh R. palmarum larvae were frozen at minus $10^{\circ} \mathrm{C}$ for 12 hours in order to obtain a suitable texture. 
$\checkmark$ Chopped: it is done with a $5 \mathrm{~mm}$ sieve and the meat ingredients are mixed.

$\checkmark$ Curing: In this step the salt, sugar and curing salts were added leaving the mixture to cool at $2{ }^{\circ} \mathrm{C}$ for six hours.

$\checkmark \quad$ I added dry ingredients and condiments: the mixture was kneaded for 20 minutes and where the flour and other seasonings were added.

$\checkmark$ Texture: The texture is made in a cutter including the above mixture the ice, during this process it is verified that the temperature of the product does not exceed $8{ }^{\circ} \mathrm{C}$.

$\checkmark$ Sausage: it was made in a hydraulic filler using 12 gauge synthetic casing dividing the sausages into portions of $10 \mathrm{~cm}$ in length

$\checkmark$ Pasteurized: This was done by immersion in water at $70^{\circ} \mathrm{C}$ for 45 minutes ensuring that the internal temperature of the sausages is at $65^{\circ} \mathrm{C}$, then cooled in ice water at $2^{\circ} \mathrm{C}$.

$\checkmark$ Packing: the packaging was done in vacuum in portions of 450 grams net weight.

$\checkmark$ Storage: The finished product is stored in cooling at $4{ }^{\circ} \mathrm{C}$.

\section{Conclusions}

It is concluded that it is possible to produce an Amazonian product from chontacuro larvae that are possible to be rich in omegas and the taste of the clients. In relation to competition, there are similar parameters. The importance of this research is the application of scientific knowledge to the training of Agroindustrial students.

\section{Bibliography}

1) Acuña, A. (2009). Estrategias de innovación y diseño de un producto. 6, 261.

2) Allende, A. (2011). Diseño del producto y proceso.

3) Ariza, A. (2009). Fases para el desarrollo del producto. Calomarde, J. (2000). Marketing Ecologico. 15.

4) Casp, A. (2012). Diseño de Industrias Agroalimentarias (Mundi-Prensa Ed. Mundi-Prensa ed.).

5) Cortés, A. (2014). ETAPAS DEL DISEÑO DE UN PRODUCTO.

6) Cortez, A. (2000). Elementos del producto. Vol. 5.

7) Chauvin, S. (2014). Diseño de Producto: 7 Pasos Para Tener Éxito.

8) Departamento de Organización de Empresas. (2007). Organización de Empresas, E.F. y C.

9) Gaither, N. (2000). Administracion de la Produccion (Octava ed.).

10) Gonzalez, M. Creacion y diseño de nuevos productos.

11) Jordi , M. (1989). Elementos de un producto. 3.

12) Lockyer, K. Elementos de un producto. 3, 87-88.

13) Machado, E. (2007). Marketing.

14) Miranda, F. (2000). La gestión del proceso de diseño y desarrollo de productos.

15) Ramirez, N. (2009). Caracterizacion y diseño de los de los resultados cientificos como aportes de la investigacion educativa.

16) Salvador, M. (2004). Mercadotecnia programada (Limusa S.A Ed. Segunda ed.).

17) Salvador, V. (2014). 7 pasos básicos para la generación de nuevos productos.

18) Sanchez, J. (2016). Diseño y desarrollo de productos y servicios.

19) Suh, N. (1990). The Principles of Design

20) Turmero, P. Conceptos básicos para el diseño de sistemas.

21) Wodehouse, A. (2010). Information use in Conceptual Design: existing taxonomies and new approaches. International Journal of Design, Vol. 4. 